\title{
How to expect God's reign to come: From Jesus' through the ecclesial to the cosmic body
}

\begin{abstract}
Authors:
Jakub Urbaniak ${ }^{1,2}$ (c)

Elijah Otu

\section{Affiliations:}

${ }^{1}$ St Augustine College,

Johannesburg, South Africa

${ }^{2}$ Department of Church History and Church Polity, Faculty of Theology,

University of Pretoria,

South Africa

${ }^{3}$ St Joseph's Catholic Church Mokoena, Katlehong,

Archdiocese of

Johannesburg, South Africa

Project leader: G.A. Duncan Project Number: 123456

\section{Description:}

Jakub Urbaniak and Elijah Otu are participating in the research project, 'Roman Catholic History in the modern era: Vatican II and beyond', directed by Prof. Dr Graham Duncan, Department of Church History and Church Polity, Faculty of Theology, University of Pretoria.
\end{abstract}

\section{Corresponding author:}

Jakub Urbaniak,

jakub-urbaniak@hotmail.com

Dates:

Received: 19 Feb. 2016

Accepted: 19 Feb. 2016

Published: 31 Aug. 2016

How to cite this article: Urbaniak, J. \& Otu, E., 2016,

'How to expect God's reign to come: From Jesus' through the ecclesial to the cosmic body', HTS Teologiese Studies/Theological Studies 72(4), a3380. http://dx.doi. org/10.4102/hts.v72i4.3380

Read online:
This study seeks to articulate the universality of the eschatological expectation, in its specifically Christian form, by interpreting it from the perspective of a radical embodiment. This can be understood in a twofold manner. Firstly, the mysterious reality of the eschatological reign of God is rooted in - and thus can be more adequately grasped through the lens of - Jesus' own body seen as distinct yet not separate from his risen body and, mutatis mutandis, from his extended body, both ecclesial and cosmic. Secondly, for the eschatological expectation to be lived out in an incarnational way, it must be 'enfleshed' in actions aimed at social and ecological liberation.

The article consists of four sections. Firstly, we explain in what sense body - and more specifically Jesus' body - is used in our analysis as a hermeneutic key to notions such as 'risen body', 'spiritual body', 'extended body', 'social body', 'ecclesial body', 'cosmic body', basar / kol basar ('flesh'/'all flesh'), and 'life'. Then, the universality of the eschatological expectation is being articulated on two levels, namely, (1) with regard to the social, and in particular the ecclesial, body, and (2) with regard to the cosmic body, with ecological implications inherent in such perspective. Finally, we close the loop by briefly revisiting the notion of Jesus' body.

There is here no longer any separation possible between the church as the particular body of Christ and the cosmos at large, for also the cosmos is reconciled to God in the shalom of reconciliation. (Gregersen 2013:260)

The essential thing is to respect and hold fast to the community of all living things. Human beings are their fellow creatures. It is only 'together', not separately, that the glory of the Lord will be visibl (Moltmann 2015:127)

\section{Introduction}

When I was an altar boy, back in Poland, my parish priest used to encourage us to 'pray as if everything depended on God, and to live as if everything depended on our hard work'. I guess one could trace the underlying insight back to the early Christian views of synergy between grace and freedom and compatibility between divine and human agency (even though today I would deem the form it received in the advice of my parish priest neither synergistic nor compatibilist).

This dubious adage could be seen as one of the possible answers to the question: 'How are we to expect God's reign to come?' Bearing in mind the specific dynamics of God's reign (already-here and/ or not-yet-fully-realised), those who believe in and wait for the final revealing of God's glory 'at the end of time' should eagerly engage in the process of transforming the world by grasping and actualising the spirit of the gospel. God makes humanity co-responsible for the fulfilment of God's promises and at the same time empowers humanity to bear that responsibility. For the gifts of the Spirit are already available to all through the ministry of Christ's church. Thus expecting God's eschatological reign to come means both to trust and to be on mission: to trust in the coming of God's eschatological reign and to actively engage in liberating earthly realities from all sorts of oppression - one not without the other. As Lohfink puts it, 'we are constantly living in a state of imminent expectation, in a space in which God's promises earnestly seek fulfilment' (Lohfink 2014:16).

1.The term 'reign of God' (alternatively, 'God's reign') is preferred in this study to the 'kingdom of God' for a twofold reason: linguistic and theological. Firstly it is more gender-inclusive. Secondly it better reflects the dynamic nature of God's rule ('kingdom' may connote both God's rule and the dominion over which God is sovereign; thus, unlike reign, it can be understood in a 'static' way).

Copyright: (C) 2016. The Authors. Licensee: AOSIS. This work is licensed under the Creative Commons Attribution License.

Note: Dr Jakub Urbaniak (PhD: UBO Brest; DTh/MTh: UAM Poznan) came to South Africa in 2010 from Poland. He is a research fellow at the Faculty of Theology, University of the Free State, and a Senior Lecturer in Systematic Theology and Philosophy of Religion at St Augustine College, a Catholic University in Johannesburg. He is also an extraordinary lecturer at the University of Pretoria, where he did his postdoctoral fellowship (2013-2014). Currently, in his research he focuses on the category of 'life' as a hermeneutic key to bridging the gap between ecological theologies and contextual/liberation theologies, with their various socialpolitical emphases.

Fr Elijah Otu is a Catholic priest of the Missionary Society of St Paul. In 2015 he graduated from St Augustine College of South Africa. His Master thesis, written under the supervision of Dr Urbaniak, focused on Jesus' eschatological expectation as interpreted through the lens of God's 'eschatological reign'. Currently, he ministers at St Joseph's Catholic Church at Mokoena, Katlehong. 
If this is what a Christian attitude, in principle, should look like, then exploring theological reasons for both trust and liberating practice needs no justification. In this study, we aim to articulate the universality of the eschatological expectation, in its specifically Christian form, by interpreting it from the perspective of a radical embodiment. This can be understood in a twofold manner. Firstly, the mysterious reality of the eschatological reign of God is rooted in - and thus can be more adequately grasped through the lens of Jesus' own body seen as distinct yet not separate from his risen body and, mutatis mutandis, from his extended body, both ecclesial and cosmic. Secondly, for the eschatological expectation to be lived out in an incarnational way, it must be 'enfleshed' in actions aimed at social and ecological liberation.

The study builds upon our article concerning the dynamics of God's reign as a hermeneutic key to Jesus' eschatological expectation, which is included in the same volume (cf. Urbaniak \& Out 2016). The present analysis consists of four sections. Firstly, we explain in what sense body - and more specifically Jesus' body - is used in our analysis as a hermeneutic key to notions such as 'risen body', 'spiritual body', 'extended body', 'social body', 'ecclesial body', 'cosmic body', basar/kol basar ('flesh' and/or 'all flesh'), and 'life'. Then, the universality of the eschatological expectation is being articulated on two levels, namely, (1) with regard to the social, and in particular the ecclesial body, and (2) with regard to the cosmic body, with ecological implications inherent in such a perspective. Finally, we close the loop by briefly revisiting the notion of Jesus' body as a unifying interpretative key.

In our analysis we critically investigate the views of selected contemporary theologians and, where relevant, refer to the findings of recent biblical exegesis. Although the material is both historical and textual, and thus requires interpretation, our perspective is that of a present-oriented constructive theology. Therefore, theological hermeneutics coincide with 'theological improvisation' (Crawford 2010, 2013).

The all-embracing eschatological perspective of Jürgen Moltmann, which entails personal, historical, and cosmic dimensions, delineates the conceptual horizon for our own approach. The views of Karl Rahner, in turn, have provided us with a christological-soteriological framework for our investigation. Our ecclesiological reflections are focused on, but not limited to, the Roman Catholic perspectives, especially as represented by Avery Dulles, Teilhard de Chardin, and Vatican II. Our constructive proposal on the cosmic dimensions of the eschatological expectation owes most to Niels Gregersen's scientifically informed Logos Christology, in particular his notion of 'deep incarnation' and his Trinitarian reflection on matter and information, as well as his theological insights on the extended body of Jesus. Other important sources related to cosmic and ecological eschatology include Elizabeth Johnson's soundings in 'deep christology' and Michael Welker's notion of 'spiritual body'.

\section{'A piece of this world, real to the core': ${ }^{2}$ All flesh as Jesus' extended body}

The mystery of Jesus' extended body can only be grasped through the double lens of the Incarnation and the Passover, ${ }^{3}$ without neglecting what his life and ministry reveal about his corporeality. Rahner famously noted that 'the statement of God's Incarnation - of his (sic) becoming material - is the most basic statement of Christology' (1975:175). But it is only in his resurrection that 'Jesus' body has become accessible worldwide' (Gregersen 2012:242). These two are so mutually correlated that only by considering them as a theological tandem can one speak soundly of God's self-communication through Jesus the Christ. Here we start off with the paschal perspective.

Paul uses the imagery of the seed and the full-grown plant (1 Cor. 15:36-38, 44) to describe the amazing continuity between the pre-Easter and the post-Easter body of Jesus. However, in the same passage he counterbalances this continuity with almost frightening discontinuities (Welker 2014:359):

the dying of the seed and an act of [new] creation by God (1 Cor. 15:38). ${ }^{4}$ Our whole perishable person will be transformed (metaschematizo, Philippians 3:21) into a new and imperishable heavenly personality that will be qualitatively different from our first. It will be - thank God - much better! (Lampe 2002:108)

Thus as the risen Christ, the firstborn of the new creation, is not present in the way that the pre-Easter Jesus was, so neither the rest of the new creation, including God's children brought to glory (Heb. 2:10), will be present in the way that our mortal, perishable bodies allow us to be currently (Welker 2014:356). This is why Paul differentiates between 'flesh' (sarx, as perishable matter) and 'body' (soma, as matter shaped by mind and Spirit). His point is to juxtapose the 'mortal body', which, as dominated by non-divine powers, will eventually decay and die, with a 'spiritual body', which will be recreated by divine grace in the resurrection (2014:359-360). In this context, Welker rightly insists on the need to 'respect both continuity and discontinuity between the life and body of the pre-Easter Jesus, of the resurrected and exulted Jesus Christ, and Christ as the ultimate Judge and Saviour of the world in his parousia' (2014:359).

Gregersen also looks at Jesus' body against the backdrop of his life and ministry. According to his insightful observation, Luke's gospel portrays Jesus as the accommodating body, which 'not only moves in time and space but is moved and

\section{Rahner (1974:128).}

3.By the 'Passover', we mean the paschal mystery of Christ which entails his passion, crucifixion, resurrection and ascension as well as the outpouring of the Spirit. Even though this point is not developed here, we will argue at a later stage that the full existential-ecological implications of the mystery of Jesus' extended body cannot be articulated without reference to the cross.

4.The author's italics. 
transformed by whom and what Jesus meets and is met by (Gregersen 2012:235).

In all four Gospels Jesus is not understood as a person in the modern sense, that is, as a psychological individual. An individuum (in Greek, a-tomos) means something indivisible, whereas Jesus becomes precisely what he is in the exchanges with others than himself. The landscapes he crosses, the people he meets, the religious culture he both embraces and oversteps belong to Jesus' body, just as his body cannot be understood without either God's Spirit animating him or without his relationship to his heavenly Father, whom he addresses in prayer and whose will he seeks to understand. (Gregersen 2012:234-235)

Already Luther conceived of Christ as the 'comprehensive person' (maxima persona) who, 'immersed in everything' (submersus in omnia), has chosen to become the maximal sinner in order to be genuinely united with sinners (Luther 1963:278; cf. also Gregersen 2013:253). Today's ecological theology, drawing from both biblical-patristic and scientific sources, extends this anthropocentric view of Christ, who came to save humanity from sin and death, in order to embrace the three overlapping life-circles comprised in Jesus' body: the spheres of nature, sociality, and person (Gregersen 2012:236). Thus never just himself, a solitary individual, Christ -'a piece of this world, real to the core', in Rahner's felicitous phrase (1974:129) - is seen as the totus Christus: 'Christ and community in one body' (Gregersen 2013:253).

In this context, speaking of Jesus' 'extended body' opens vast interpretative horizons. The traditional theological understanding of church as the mystical body of Christ falls quite naturally under this category. Through the resurrection and ascension Jesus' body disappears and goes into God and into his church; from now on it is present, as a social body, in the fellowship of the Holy Spirit. In the next section, we will look more closely at some implications of and potential difficulties related to such a bodily ecclesiology.

If the Logos can be interpreted as the 'informational matrix for the concrete forms that have emerged and will emerge in the world of creation' (Gregersen 2014:342), then what can be said about the sarx that the divine Logos became? Put differently, if Logos became sarx, in what is God really incarnate?

Mary Douglas argues that the biological and the social body belong together as a microcosm and a macrocosm (1996:69-87). Her anthropological insight may be adapted theologically: in Jesus' own body (which, as we have seen, is never really only his own), Logos incarnate establishes, through the Spirit, a living connection between God and all flesh (Gregersen 2012:244). Moltmann suggests (2015:127) that the Hebrew term basar - especially in the phrase kol basar (lit. 'all flesh') - can best be translated 'life'. Johnson goes even a step further when she claims that 'in a deeply real sense, the meaning of flesh/sarx encompasses all matter' (2015:138). Thus, in the incarnation, the divine Logos unites itself not only with life, but also with the very basic physical stuff (Gregersen 2014:344).
Jesus' body appears, therefore, as extraordinarily open in relation not only to God and his fellow humans, but also to sensitive creatures ('sparrows' and 'foxes'), whose pains he himself has experienced, to all biological life-forms ('grass' and 'lilies'), whose fate he himself has shared and ennobled, and ultimately to the matter as such ('all flesh'), whose material conditions of creaturely existence he himself has conjoined (cf. also Gregersen 2012:239, 2015:225-226). 'Transformed from a biological, cultural body into an extended body - a kind of body-fellowship' (Gregersen 2012:243), Jesus' body can be now seen not only as a hermeneutical key to social bodies and cosmic matter, but indeed as the most elementary 'eschatological material' of all flesh.

How does such an understanding of Jesus' extended body translate into the eschatological language of expectation, specifically with regard to the social body of the church and the natural cosmic body of the universe? To this question we now turn.

\section{From Jesus to the ecclesial body: Church vis-à-vis God's reign}

According to Rahner's hermeneutical principle, all eschatological statements are extrapolations in faith 'from presently received grace to its definitive fulfilment' (Musser \& Price 1996:383). Bearing in mind Rahner's transcendental view of grace, one may argue that eschatological expectation is ingrained in the very composite nature of humanity; that it belongs to the essential historicity of the human person (Rahner 1966:330). In his discussion on the hermeneutics of eschatological assertions, Rahner himself postulates that:

If man (sic) is a being involved in history, which means more than a merely external temporal succession such as holds good for physical objects, he cannot understand himself in any given present moment without an aetiological retrospect towards a genuinely temporal past, an 'anamnesis', and without prospect of a genuinely temporal future. His self-understanding embraces beginning and end of his temporal history, both in the life of the individual man and of humanity. Anamnesis and prognosis are among the necessary existentials of man. (1966:330-331)

In other words, the very constitution of human nature is such that the human person is naturally inclined to concerns about the future, wanting to know what the future holds in store, which is necessary to one's present existence. But is it justifiable to call such an expectation 'eschatological'? Rahner defines the knowledge of the future as 'knowledge of the futurity of the present' (1966:332; our italics). Like Moltmann, he understands eschatology as an all-embracing notion: Eschatological knowledge is knowledge of the eschatological present orientated to the future (1966:332). In other words, the knowledge of the future is always a moment in one's knowledge of the present. 'This alone', Rahner concludes, 'is sufficient to give the content of eschatological knowledge the character of hiddenness' (1966:332; our italics). Put simply, not everyone expects heaven, but everyone expects.

However, such an existential account of eschatological expectation is not sufficient to justify the centrality thereof in 
the experience of the church. This can be done only by means of referring to God's eternal promises being fulfilled once and for all in the Christ-event. The decisive irruption in history of Jesus Christ marks both an end, an eschaton, as well as the beginning insofar as it creates the possibilities for a new way of life now embodied in the church (DeCosse 2015:644). From the Christian perspective, then, eschatological expectation is not a timeless anthropological fact. Rather as 'we know there was a beginning [the creation] because we have seen the end [the Christ-event]' (Hauerwas 2013:12), so we expect the new beginning (the parousia) because we now, as the church, experience the reality of the inaugurated eschatological reign (Robinson 1957:157, 161; McBrien 1966:44-73). Thus the very existence of the extended social body of Jesus, appears not only as 'a witness to the created nature of our existence' (Hauerwas 2013:12), but also as witness to the penultimate character of our lived reality (Gregersen 2014:325).

Jesus' own eschatological expectation should not be considered in isolation from his historical-cultural background (Urbaniak \& Otu 2016). Generally, among the Jews contemporary to Jesus there was an expectation that Yahweh would come soon to establish God's rule forever. According to many scholars, the coming of the kingdom was, so to speak, the talk of the day. It seems evident in his preaching that Jesus must have shared, at least to an extent, the hope for God's final victory, prevalent particularly among the revolutionists whose base of operation was Galilee (Fuellenbach 2006:215; Keener 2009:254).

The early church, which has continued the ministry of Jesus following his great commission (Mk. 16:15-18), did not depart completely from this frame of mind. The letters of Paul (1 Thess. 4:13-18. 2 Thess 2:1-4) and Peter (2 Pet 3:8-13) bear witness to the eschatological expectation of the apostolic communities. Christians of the first and second centuries believed the end was near, and they hoped for a radically better life for themselves, because they believed Jesus had risen from the dead, and because they considered the experiences of the charisms of the Spirit, common in those communities, to be the concrete foretaste of God's reign. After the era of the Apostles, the church continued to anticipate the final consummation of the age.

It will not be an exaggeration to say that despite the apparent delay (or the repeatedly failed and/or mistaken predictions) of the end, so do the Christians of the twenty-first century expect God's reign to come. As Daley suggests (1991:3), the church has always looked forward to the parousia, the second coming of Christ, with all that it signifies, as something near, something 'at the gates' (cf. Mk. 13:29), for that is precisely the attitude that the gospel recommends. However, from the perspective of the two millennia that has passed since the historical Christ-event, the fact that the world, as we know it, did not end, certainly poses a theological challenge. ${ }^{5}$ One of the essential questions it raises is that regarding the relationship between the present and the future reality or, put more narrowly, the relationship between the church and God's reign. Before we apply our experimental bodily approach to deal with this question, let's look at some more traditional theological trends.

The view that the church is coextensive with the reign of God dominated the thinking of the first apostolic communities. Dulles (1971:70, 1985:97-98) claims that in their vision of the church, the New Testament writers generally agree that it belongs to the end-time. The early chapters of the Acts of the Apostles represent the church as an eschatological reality within historical time, the convocation of the saints that will be realised to the full at the eschaton. At the dawn of the Patristic era the Church was also seen as being essentially ordered towards its consummation in the realised reign of God. ${ }^{6}$ Christian writers throughout the patristic and medieval periods constantly spoke of the two forms of the church: 'an imperfect earthly form in which the church was still struggling to achieve its true reality, and a perfect, heavenly form in which the church enjoyed the blessed vision of God' (Dulles 1985:99). A later division between ecclesia militans and ecclesia triumphans has prevailed until the twentieth century. In contrast to the earlier periods, however, in modern times the term 'church' has been almost exclusively identified with the 'pilgrim' or 'militant' church.

Many prominent theologians of our times think of the church precisely in this line: as a this-worldly reality which will cease to be at the end of time. Such an understanding of the church lies at the roots of the distinction, indeed (in some cases) of the juxtaposition, between the church and God's reign. In Küng's words (1968:92-93), ecclesia is the work of humanity, whereas basileia is the work of God. Similarly, Pannenberg holds that 'Christ points the church toward the Kingdom of God that is beyond the church' (1969:76-77). Rahner likewise maintains that the church 'is living always on the proclamation of her own provisional status and of her historically advancing elimination in the coming kingdom of God towards which she is expectantly travelling as a pilgrim' (1969:298).

And yet Lumen Gentium, which devotes an entire chapter to 'The Eschatological Nature of the Pilgrim Church and Her Union with the Heavenly Church', clearly points to the continuity, indeed an organic connection, between the church and the reign of God. In fact, the document describes the church as 'the kingdom of Christ now present in mystery' (LG, §3 [1964]). What underlies the conciliar teaching is the idea of the church as a sacrament of universal salvation (LG, §48). As Dulles holds (1971:83), the church is not to be simply identified with the reign of God in its final and full form, but it is a true anticipation thereof, and everything that authentically expresses the church is a sign of God's reign that is to come. In this context, the church is seen as eschatological insofar as it is a sacrament of the eschatological

6 This eschatological orientation is attested in the Didache The Shepherd of Hermas, etc. In the latter etc. In the latter the Church is represented in the form It is not, and will not be finished until the last day, at the time of the parousia, which, moreover, is imminent (Hermas 1997: Similitude 9; cf. also Daley 1991:17; Dulles 1971:72-73). 
reign of God. As a sacrament, that is, a symbolic embodiment of God's reign, the church betokens the actual presence, though in a hidden way, of that reign (Dulles 1985:107-108).

It is at the Eucharist that the church becomes more than ever a sacramental sign of the heavenly Jerusalem (SC, §2; §41 [1963]). To use the language of Hans Urs von Balhasar, 'the celebration of the Eucharist most openly displays the presence of the church in the theo-drama of Christ' (Lösel 2001:210; cf. von Balthasar 1964:94). Thus it anticipates eternity in the ongoing course of time and history, albeit in a hidden-mysterious way in which only believers can recognise the real presence of the whole Christ-event, with its inherently eschatological orientation (Von Balthasar 1964:96). Welker points out that in the Eucharist 'bread and wine participate in the edification of the spiritual body' (2014:361), i.e., body recreated by God's grace in the resurrection. 'Whose body are we talking about?', one may ask. The first and fundamental answer is Christ's. But, as we have seen, in the eschatological perspective this cannot be radically separated from the extended mystical body of the risen one, i.e., from his church, and thus from the body of each and every member of the 'new creation', now symbolically edified by the eucharistic 'elements':

The gifts of creation (not just gifts of nature, but gifts of the interaction between nature and culture and thus already richly blessed by the working of the Holy Spirit!) become gifts of 'new creation'. Bread and wine not only symbolically edify the natural bodies of the community assembled. As 'bread and wine from Heaven', as the body and blood of Christ, they edify the members of the body of Christ... Here the continuity between creation and new creation, between creation old and new becomes palpably present in the middle of the overwhelming discontinuity. (Welker 2014:361)

Another angle from which the universality of an eschatological expectation can be looked upon is found in the essential connection between the eschaton, on the one hand, and Christian mission, on the other. Here the notion of embodiment appears on a still different level: it is the spirit of the gospel that is being embodied, 'enfleshed' into the world through the ministry of the church, and more precisely through its proclamation, manifestation, and prophetic action (Tracy 1981:371-405). In the words of Vatican II's Decree on the Missionary Activity of the Church:

The time for missionary activity extends between the first coming of the Lord and the second. Then from the four winds the Church will be gathered like a harvest into the kingdom of God. For the gospel must be preached to all nations before the Lord returns. (AG, §9 [1965a]; cf. also Mk. 13:10; Matt. 24:14; Matt. 28:20)

The idea that the church is inherently eschatological because it cooperates with God's grace, with the Spirit present in its midst, to prepare the world for the final consummation, played an important role in the theology of Oscar Cullmann, a Protestant biblical theologian who conceived of the church's missionary activity itself as an eschatological sign. According to Cullmann (1950:160-162), the era of the church - that is, the period between the resurrection and the unknown date of the Parousia - has its theological meaning as the interim during which the gospel is to be preached to all the nations; it is a time of grace granted to humanity by God.

Perhaps one of the most radical views regarding the relationship between the church and God's reign in an eschatological context is that developed by Teilhard de Chardin. The French Jesuit held that human (and particularly ecclesial) activity in building the earth is a vital ingredient of the future reign of God, and a condition sine qua non of the parousia (Dulles 1985:112). In de Chardin's own phrase:

We continue from force of habit to think of the Parousia, whereby the Kingdom of God is to be consummated on Earth, as an event of a purely catastrophic nature- that is to say, liable to come about at any moment in history, irrespective of any definitive state of Mankind (sic). This is one way of looking at the matter. But why should we not assume, in accordance with the latest scientific view of Mankind in an actual state of anthropogenesis, that the parousiac spark can, of a physical and organic necessity, only be kindled between Heaven and a Mankind which has biologically reached a certain critical evolutionary point of collective maturity? (De Chardin 1964:266-267)

Although the Catholic Church has never officially followed, or even approved, de Chardin's interpretation of the relationship between human growth and the coming of God's reign, Vatican II nonetheless emphasised the continuity between human values such as dignity, freedom, brotherhood (and sisterhood, we shall add) to be realised within history, and their fulfilment in the eschatological reign of God (GS, §39 [1965b]). The Council speaks of the world in terms of the fruit or the flower, using the language of growth and development, in order to present it as an arena where 'all the good fruits of our nature and enterprise' $(G S, \S 39)$ are to be realised. In this context, the hope of God's reign is brought to bear as a motive for seeking justice and peace on earth (Dulles 1985:111-112): 'On this earth that kingdom is already present in mystery. When the Lord returns it will be brought into full flower' (GS, §39). In the same vein, Moltmann states that " church for the world" can mean nothing else but "church for the kingdom of God" and the renewing of the world' (1967:327). In this sense, the church is for Moltmann 'like an arrow sent out into the world to point to the future' (1967:328).

One may sum up these approaches by stressing that Christian mission entails a responsibility for the world; hence the church's task to introduce the values of God's reign into the whole of human society and thus prepare the world - insofar as human efforts can - for the final transformation when God will establish the new heavens and the new earth (Dulles 1985:114).

Is there anything more that can be said about the relationship between the church and God's reign, if one uses Jesus' extended body as a hermeneutic key?

While describing the transformation of Jesus' individual body into his extended body, Gregersen refers (2012:242-243) 
to two evocative scenes from Luke: the Emmaus story and the ascension. When the eyes of the disciples were opened and they recognised Jesus, he 'vanished from their sight' (Luke 24:31). ${ }^{7}$ Thus understanding and faith seem to be mysteriously correlated with the absence of Christ's resurrected body. 'At the moment of this new transfiguration', Gregersen points out, 'only the social body is present, of which they themselves are a part - indeed, which they themselves are' (2012:242). Similar dynamics can be observed in the scene of the ascension. When Jesus takes his disciples out of the city and raises his hands in blessing over them (Luke 24:50), one can hardly overlook the analogy to the last supper when he said of the bread, 'This is my body' (Luke 22:19). Jesus' intention here seems to be clear; he wants to make the disciples themselves his body from now on (Gregersen 2012:243).

Thus wherever bread is broken in the community of disciples gathered around Jesus' words and self-sacrifice in the Eucharist (cf. Luke 22:14-20), and wherever repentance and forgiveness of sins are proclaimed in his name to all nations (cf. Luke 24:47), Jesus' extended body is present and alive (Gregersen 2012:243). However, two significant caveats must be made.

Firstly, this does not mean that Jesus' own body is now dissolved in the social body of the church:

The point is rather that his body and story identify who Jesus Christ is and always will be, where he is to be found by his disciples and all others, and how he and the Father will act in the future. As he was, so will Jesus always be and act. In this sense the church can never separate itself from Jesus' body. But at the same time Jesus' body has become a social body, an extended body. (Gregersen 2012:243)

This also means that the only way to adequately interpret the relationship between the church and God's reign leads through Jesus' body. Put simply, the church falls short of its proclamatory, sacramental, and prophetic vocation whenever it fails to 'enflesh' Jesus' word, presence, and active love in a faithful manner. On the other hand, insofar as it allows the Spirit to transform its frailty and sinfulness into the source of grace, it makes tangible God's reign here and now, in the anticipation of its full glory.

Secondly, the godlike quality of the extended social (ecclesial) body of Christ must not be understood in an exclusivist manner. Rather, it should be interpreted as a sacramental presence which reveals and renders both the relative omnipresence of Jesus' extended body ${ }^{8}$ as well as its ultimate wildness and untameability. In this sense, the risen body of Christ is like God's reign: 'The kingdom of God is not coming with things that can be observed: "Look, here it is!" or "There it is!" for, in fact, the kingdom of God is among you' (Luke 17:20-21). Peter once tried to preserve something of God's glory at the top of a mount of transfiguration; it didn't work, 7.All Scripture references are quoted according to the NRSV Catholic Edition.

8.Why 'relative' will be explained in due course. for God's reign is untameable. Analogically, no church, no religious group may build dwellings that would be capable of containing Jesus' body (these words do not come naturally to a Catholic theologian who regularly looks with reverence at the tabernacle...). Like God's reign, so Jesus' extended body is among us in the world of creation, accessible worldwide. (Gregersen 2012:243-244).

\section{From ecclesia to cosmos: Towards a spiritual body}

What has been said above about Logos uniting itself, in Jesus' body, with all flesh and thus rendering God accessible worldwide (or should we say universe-wide), finds its theological foundation, together with far-reaching ecotheological implications, in the notion of 'deep incarnation'. It has been coined by Niels Gregersen and creatively elaborated upon by other theologians like Elizabeth Johnson and Jürgen Moltmann, to mention only a couple. John's Prologue lies at the centre of this christological proposal:

For the concept of deep incarnation it is important that the divine Logos became sarx (Jn 1:14): not just as a human being (anthropos) as opposed to other species, and not just as an individual man (aner $r$ ) as opposed to being a woman. It was as flesh that the divine Logos 'lived' or 'dwelled' among us (Jn 1:14). The flesh is not only the principle of individualisation (as in Aristotle and Thomas Aquinas) but also the principle of sharing, namely sharing a bodily existence, based on a common physical matrix and living under similar biological conditions. (Gregersen 2013:260)

In the incarnation, Jesus' body becomes not only an 'exemplar of humanity', but also an 'instantiation of the "frail flesh" of biological creatures' (Gregersen 2014:344). Christ as the incarnate One, has immersed himself into the grains of creation and into the biological conditions that humankind shares with other life forms (Gregersen 2013:253-254). In other words:

God's own Logos (Wisdom and Word) was made flesh in Jesus the Christ in such a comprehensive manner that God, by assuming the particular life story of Jesus the Jew from Nazareth,... reache[d] into the roots (radices) of material and biological existence as well as into the darker sides of creation: the tenebrae creationis. (Gregersen 2015:225-226)

Luther once remarked that 'what is born from eternity is born every moment' (1883-2009:39/II, 293; quoted after Gregersen 2013:261). Put in Pauline language:

Even though incarnation happened at a particular date in history, it was decided for in eternity (Eph 1:4-10) and was aimed for all times and places (Col 1:15-20) ... if incarnation is deep in flesh, it is also deep in time, in so far as time, space, and eternity are interwoven. (Gregersen 2013:256)

This means that the incarnation is not merely a passing episode in God's involvement with the world of creation. Rather, incarnation must be seen as a perpetual reality, for once Logos has become sarx - 'there shall be neither separation nor confusion between Christ and creation' (Gregersen 2013:260-261). 
A radical embodiment presupposed by deep incarnation can be also read through the lens of the old patristic axiom: 'What is not assumed cannot be healed'. For centuries this soteriological principle has been interpreted almost exclusively in an anthropocentric manner, even though the church Fathers had already developed a profound cosmic christology. ${ }^{9}$ In our day, ecological theology widens this anthropocentric focus to include biocentric and cosmocentric dimensions (Johnson 2014:223, 2015:133). Johnson, for instance, speaks of Jesus as God's Word/Wisdom (Sophia) who 'entered into solidarity with the entire biophysical world of which human beings are a part and on which their existence depends' (2015:140).

This has formidable ramifications not only for the creation, but also for God's own self (which is never really only God's own). For in the Christ-event - from cave to cross and resurrection - God has entered 'into the sphere of the materially vulnerable and mortal to shed light on all from within' (Johnson 2015:134), but at the same time the entire matrix of materiality has been assumed in Jesus' body and blood, and thus into God's own life (Gregersen 2013:252). It is Logos made sarx that Paul has in mind when he says, 'In him the whole fullness of deity dwells bodily' (Col. 2:9). In the same vein, Rahner states that 'the climax of salvation history is ... taking on of matter so that it itself becomes a permanent reality of God' (1982:160).

What about the specifically eschatological implications of such a 'deep christology'? ${ }^{10}$ In analogy to Gregersen's deep incarnation, Johnson suggests the notion of 'deep resurrection' as a way of pushing personal and even historical eschatologies beyond their human scope 'to include a blessed future for the whole natural world' (Johnson 2015:148; cf. also Johnson 2014:208-213). Deep incarnation is thus continued in the deep resurrection of the social and cosmic body into God's Trinitarian life (Gregersen 2013:260). In this context, Welker speaks of a 'spiritual body' (Pauline soma in contrast to sarx) which expresses both continuity and discontinuity between the mortal flesh dominated by non-divine powers, and the immortal flesh mysteriously transformed by divine grace in the resurrection (Welker 2014:359-360).

Deep resurrection thus understood also implies the reinterpretation of the Jewish symbol of God's reign central to Jesus' preaching and deeds. In its ultimate eschatological sense, this symbol evokes, as Johnson reminds, of 'the moment when God finally triumphs over the powers of evil and the divine will is done on earth as it is in heaven' (Johnson 2015:144). From the perspective of deep resurrection it becomes clear that the coming reign of God will effect nothing less than redemption and the end of sin, suffering, and death in favour of flourishing of all creatures' (2015:144). As the ultimate divine purpose, God's reign 'gives order and direction to the world - not just to a slice of the world, but to

9.For instance, Ambrose of Milan boldly preached that "In Christ's resurrection the earth itself arose' (Patrologia Latina 16: 1354 [1880]).

10.This term used by Elizabeth Johnson seems to encompass her reflection on deep incarnation, deep resurrection, deep ministry, as well as christic paradigm (Johnson 2015). the whole world in its evolutionary history' (2015:144). In the same vein, Moltmann points out (2015:123):

The resurrection of Christ has to be grasped not only in the framework of a historical eschatology, but in cosmic eschatology too. The risen Christ is not just a hope for eternal life given to mortal human beings; he is also the future of all things in a 'new heavens and new earth, where righteousness is at home.' (2 Pt. 3:13)

Such broad, inclusive views of incarnation and resurrection have far-reaching implications for eschatological expectation. If, as Isaiah says, 'the glory of the Lord shall be revealed, and all flesh shall see it together' (40:5; our italics), 'it is only "together," not separately, that the glory of the Lord will be visible' (Moltmann 2015:127). This means that the social body of Christ, the church, cannot expect God's reign otherwise than by continuously deepening its understanding of and commitment to the solidarity with all bodies, those of humankind and otherkind alike.

Without a doubt, the role of humanity in this enterprise called 'the eschatological expectation' is unique (as is, by the way, the role of all other species and forms of material existence). As 'the part of nature in which nature becomes aware of itself' (Moltmann 2015:128), the human being can be seen as 'a hypostasis of the whole cosmic nature' (Stăniloae 1985:294). But if such a view is not to lapse into another, perhaps more subtle, version of anthropocentrism, one has to keep in mind that what we symbolically interpret as a 'hypostasis of the whole cosmic nature' exists, on the very biological and ecological levels, in a natural affinity with all other living things. In Moltmann's phrase, 'The earth is not just the habitat shared by all the living; it is also their womb' (2015:128). This view is accounted for by modern scientific research and, at the same time, it finds various metaphorical expressions in the biblical tradition (cf. Gn. 1:24; Gn. 3:19).

If there is any universal principle that one could venture to apply to all creation as it groans expecting 'the redemption of our bodies' (Rm. 8:23), it is perhaps to expect God's reign the way that God does. For humankind, it means, first and foremost, by embracing all the others and sharing what is there to share. Sallie McFague sums it up in a pithy axiom: 'Liberating, healing, and inclusive love is meaning of it all' $(1993: 161)$. This is the core of what she labels the christic paradigm (1993:162-178). Gregersen (2013) expresses a similar insight when he writes:

In incarnation God realised his own being as eternal love by embracing the lowlands of creaturely existence, and 'exalting' the world by bringing the world of creation back into the communion with God ... Love is the motivating basis for incarnation, and has reunion and mutuality as its goal. (p. 257)

To take this reflection a step further it may be helpful to ask about a theological matrix for the postulated inter-species, and indeed universal (cosmic) solidarity in the eschatological expectation, a solidarity with all flesh including both living creatures and, mutatis mutandis, the very basic physical stuff. This question transcends the framework of a traditional 
Christian theology of religions. And yet - as long as one chooses to ask it from within the Christian tradition - it cannot fail to encompass the major challenge faced by the proponents of religious pluralism, namely the scandalon of Jesus' particularity in the context of the Trinitarian dynamics of God's self-giving love.

Gregersen points out (2014:343) that in the first centuries of the Common Era Christians departed from the Stoics in their insistence on the pre-material status of the divine Logos for the sake of retaining a Jewish and Platonic sense of God's transcendence. This is when the notions of logos asarkos (a 'fleshless Logos') and logos ensarkos (an 'enfleshed Logos') were coined, wherein one existed before the other. ${ }^{11}$ As a consequence, later theology has had a tendency to conceive of God's life in terms of temporal sequences, 'as if there existed three separate stages in the "nature" of Jesus Christ (pre-existence, incarnation, and exaltation)' (Gregersen 2013:256). In contrast to such a static and purely interventionist view of God's engagement with God's own creation, Johnson suggests to take as a point of departure 'a Trinitarian understanding of God who exists eternally in a perichoresis of mutual relations' (Johnson 2015:133-134). She writes:

In such a relational theology of God, it is precisely not the case that the transcendent Holy One enters the world for the first time in the historical person of Jesus Christ. Rather the Triune God is pervasively present as self-communicating Love throughout the cosmos from the beginning of time to the end. (Johnson 2015:134)

Thus the divine Logos is present not only locally, in the particular body of Jesus, but also universally, as Creator and as Redeemer, at the very core of material existence (Gregersen 2014:344). According to such a coterminous logic, God is actively creating 'within, through, and under the guise of material processes' (2014:325). To unpack this statement in Trinitarian terms, Gregersen refers to Logos as the 'informational principle' and to Spirit as the 'energising principle' (2014:325). 'It is only in the interplay between information (Logos) and energy (Spirit)', he points out, 'that the world of creation produces evolutionary novelties rather than mere repetitions' (2014:325; cf. also Gregersen \& Görman 2007:307-314). Although some of the aspects of this creative activity have a rather strong law-like character, others rely on more contingent historical processes:

Seen from this historical context and applied to today's context of an informational universe, the divine Logos could be seen as the informational resource active in the world of creation, both by generating distinctiveness from within the core of stochastic quantum processes, by channelling energetic drives via thermodynamic processes, by building up and reshaping biological structures, and by facilitating connections and communication at whatever level possible. (Gregersen 2014:345)

Thus Gregersen interprets the 'flesh' of the material world, all flesh, in light of John's Prologue. Both social and cosmic bodies are seen here as being 'saturated by the presence of the divine Logos, who has united itself with the world of

11.At the same time, as Gregersen notes (2014:343), the early Christian writers balanced this 'Platonising' element with a strong 'Stoicising' doctrine of the incarnation of the Logos: 'Logos became flesh (sarx)' (Jn. 1:14). creation' (Gregersen 2014:345). But depending on nature, attributes and capacities inherent in particular forms of matter, be it alive or not, Logos enters and saturates the bodily realm in various ways. Gregersen classifies them under four major types of activity, namely, (1) by creating differences ('cutting information'); (2) by shaping and reshaping ('instructing and building up'), (3) by creating constructive resonances between organisms and their environments ('absorbing and connecting') and (4) by making meaning and communication possible ('making sense' of things) (2014:345). Welker suggests the notion of the 'spiritual information' (Welker 2014:361) to summarise all these different modi operandi of Logos which causes 'sometimes dramatic but most often only very calm emergent transformations' (2014:361) at the core of material existence.

In this context, many theologians whose views are quoted here postulate 'a clear coordination between the self-giving of God in creation and the thorough self-giving of God in incarnation, without reducing the latter to the former' (Gregersen 2013:258). Creation, whose aim is the flourishing of all flesh, and incarnation, whose ultimate aim is the recreation of all flesh into a new 'spiritual body', are eventually 'two expressions of the selfsame divine love... The particular and the universal walk together' (2013:258-259). However, it is equally important to avoid the risk of simply reducing the meaning of incarnation to that of creation, and hence allow its scandalous particularity to dissolve in the universality of God's all-embracing love. Here Moltmann's distinction comes in handy. While speaking of God's Spirit being 'poured out on all flesh' (Acts 2:17; cf. also Moltmann 1992), Moltmann (2015) insists that this outpouring should be distinguished from the incarnation of God's Son:

The incarnation takes place in the one - Jesus Christ - for many; the outpouring of the Spirit takes place in many so that they may be united with the one head, Christ. That comes about both in the church and in the cosmos, for the human being receives 'the breath of life' from God's Spirit (Gen 2:7), just as do all living things and the earth itself: 'When you send forth your spirit, they are created, and you renew the face of the ground' (Ps. 104:39) (p. 129; authors' own italics).

Moltmann's point that this comes about both in the church and in the cosmos should be emphasised. As far as the bigger picture is concerned, Jesus' extended body, in all its pluriformity, undergoes the process of proliferation ${ }^{12}$ which assumes different forms on biological and physical levels. Recent theories about the shrinking of the universe have seemed to quickly lose their initial appeal under the critique of the scientific milieu. Thus the view that universe is expanding remains the common notion in our day. ${ }^{13}$ Against such a background, the pneumatological insight about the multiplicity of bodies - social and cosmic alike - having their

12.This remains true, notwithstanding the fact that many living species have disappeared and still more are under threat of extinction in our day due to environmental degradation.

13. Without engaging with a proper scientific argument, one can just recall a few recent online publications indicative of this status quo: (Cartwright 2013; Moskowitz 2012 Saul 2013; Smeulders 2013: 780-783; University of Arizona 2015). 
ultimate destination in the union with the one head, Christ, appears anything but obvious.

It cannot be adequately understood and articulated by theology itself - not to mention theology in dialogue with science - without taking into consideration its 'christological twin' which speaks of embodiment taking place in the one for [the sake of] many. This 'incarnational principle' seems to be more in tune with scientific view of the universe, as exemplified inter alia by Gregersen's interpretation of divine Logos as the 'informational matrix for the concrete forms that have emerged and will emerge in the world of creation' (2014:342).

However - and this is an important digression - the mere fact that there is a potential for integrating certain theological truths with scientific views, whereas other truths seem, at least at this stage, to be going against the current of scientific discourse, should not make theologians particularly nervous. To quote the classic:

It seems a priori improbable that the truth should be so nicely adjusted to our needs and powers as that. In the great boarding house of nature, the cakes and the butter and the syrup seldom come out so even and leave the plates so clean. Indeed, we should view them with scientific suspicion if they did. (James 1956:22)

Moltmann puts it even more squarely when he points out that 'dialogues about truth develop out of contradictions' (2015:131). At the end of his article titled 'Is God Incarnate in all that is?', he makes a pointed comment about a possible contribution that Christian eschatology can make in its dialogue with modern science.

If cosmic eschatology is a constitutive part of Christian faith, then we shall also be able to talk about a deification of the cosmos in the coming of God into this creation..$^{14}$ This certainly cuts across all cosmological trend analyses. It also cuts across the evolution of life on this planet through birth and death. But it is the most important thing we can say theologically about the future of the cosmos and the future of life. Everything else is generally merely a reiteration of what the sciences themselves already say about the cosmos and the evolution of life, and there is no need for it to be said again by theologians. (Moltman 2015:131)

Therefore, both sides of the 'soteriological equation' need to be duly articulated: the 'enfleshing' of the One for many and the outpouring of the Spirit in many so that they may be united with the One. Only Jesus' body - as Logos incarnate in the Jew from Nazareth and as his extended body, social and cosmic alike - creates a living bond between the penultimate reality of the world and the ultimate reality of God (Gregersen 2014:345). This bond is living and lifegiving, in the ultimate eschatological sense, because of the Spirit who, as the 'energising principle', is pervasively present and active throughout the cosmos from the beginning of time to the end (2014:325; Johnson 2015:134).

\section{And back to Jesus' body}

This study sought to articulate the universal character of the eschatological expectation by interpreting it from the 14.Cf. Moltmann (1996:257-320). perspective of a radical embodiment, and more specifically by using Jesus' body as a hermeneutic key to all flesh. The social body of the church and the natural body of cosmos have been interpreted through the lens of Jesus' extended body. All flesh is to be recreated by divine grace into a 'spiritual body' in the resurrection at the end of time. And in this sense God's reign is to be expected by all flesh in the godlike (universal and mutual) solidarity, which on the human level should manifest itself in embracing all the others and sharing what is there to share.

It is time to close the loop by qualifying the eschatological perspective which emerges from the above picture. This will be done by means of revisiting the notion of Jesus' body as a unifying interpretative key which allows for articulating both the scope and the quality of God's reign (Moltmann) as well as for encompassing both passion for social justice and ecological concerns (Johnson).

Müller-Fahrenholz describes Moltmann's theology as 'a single great exploratio liberationis dei, as an investigation of liberation by God', at whose centre stands Christ, 'the Crucified One as the Risen One, the Risen One as the Crucified One' (Müller-Fahrenholz 2001:222). In Moltmann's eschatology, 'as much as the resurrection describes the scope of the kingdom, so the cross describes the quality of this kingdom' (Müller-Fahrenholz 2001:222). The same body and yet not the same: here crucified, there glorified continuity and discontinuity going hand in hand:

Investigating the scope of the kingdom has directed Moltmann's gaze to the dimensions of universal history and the cosmos. If and when the kingdom of the Risen Christ goes out, it not only goes beyond the death of the individual human beings but also transcends the 'death' of human histories and the 'death' of the universe, for its goal is the new creation of all things... However, if one wanted to emphasise only this dimension of the kingdom, one would quickly get near to enthusiastic arrogance and untroubled forgetfulness of the massive torments of our historicity. Therefore Moltmann has time and again directed his attention to the cross of Jesus Christ. For it is the suffering God whose kingdom comes to us. (Müller-Fahrenholz 2001:222-223)

Put metaphorically, unless - like Thomas - one sees the mark of the nails in his hands, and puts one's finger in the mark of the nails and one's hand in the side of the risen Christ (cf. Jn 20:25), one is in danger of overlooking the critical dimension of the Christian eschaton, namely the fact that God's reign comes always through the cross, and thus it is the most costly grace that transforms the old creation into the new one. This is why solidarity with all flesh means seeing the world with the eyes of the suffering God, for 'there are many things that can only be seen through eyes that have cried' (Oscar Romero; quoted after Cottrell et al. 2015:18). The 'comrades of the kingdom' are called to be drawn into messianic compassion, to become 'particularly "clearsighted" and sensitive to the suffering of the creatures of God' (Müller-Fahrenholz 2001:223), the marginalisation of the poor, women, black, LGBTI people, etcetra, and the great ecological dangers alike. 
Johnson makes a similar point when she speaks of Jesus' 'deep ministry' as a clue which allows for holding social and ecological justice in the same line of vision. She believes that Christology can 'encompass ecological concerns without losing passion for those who are suffering want' (Johnson 2015:142-143). Here Jesus' bodily attitude during his lifetime on earth, especially his openness towards the despised and marginalised bodies - what has been referred to earlier on as accommodating body (Gregersen 2012:235) - becomes a very practical inspiration and model of the discipleship.

Economic poverty coincides with ecological poverty, for the poor suffer disproportionately from environmental destruction... social injustice has an ecological face. Ravaging of people and of the land go hand in hand... The moral goal becomes ensuring vibrant life in community for all... comprehensive justice for all... Deep incarnation as enacted in Jesus' ministry underscores the dignity of all that is physical, for bodies matter to God: all bodies, not only those that are beautiful and full of life but also those damaged, violated, starving, dying, bodies of humankind and otherkind alike. Jesus' ministry grounds compassion for all the bodies in creation. (Johnson 2015:154, 145)

Thus anyone who is a 'comrade' of God's reign is called to live in active solidarity with all flesh, Jesus' extended body, while waiting expectantly for its redemption from everything that oppresses and torments it (Müller-Fahrenholz 2001:222).

In retrospect, we acknowledge one significant shortcoming of the eschatological perspective emerging from our study. It does not do justice to the non-divine powers that are at work in the world of creation, powers so dramatically depicted at the cross of Christ, namely Death and Empire. Creating and re-creating God is present through the life-giving Spirit at the very core of the material existence in Jesus' extended body, social and cosmic alike. This radical embodiment constitutes the ultimate divine 'Yes' to life and existence at large against the powers of sin and destruction. Thus God surrounds and carries all flesh towards a new heaven and a new earth where it will be 'enfleshed' into a 'spiritual body' (Welker 2014:357).

However, in its present condition, both social and cosmic bodies are susceptible to corruption. This is what Paul has in mind when he states that sarx, whose fleshly energies fall short of aiming at the existence of a 'spiritual body' and thus are bound to 'sin and death', is ultimately doomed to decay and death (cf. Rm. 8:12-13; cf. also Welker 2014:360). Put in existential terms, 'this world is full of ambiguity and despair... because of the inert brutality and finitude of life in the flesh... [and] because of creaturely co-creative freedom and its potentials to misuse' (Welker 2014:360; our italics). The former can be epitomised by the powers of Death, whereas the latter by the powers of Empire, wherein personal sin is considered as always being rooted in and contributing to ${ }^{15}$ the social structures of corruption. Such anthropological-social realism has farreaching eschatological implications which, in this study, have not been duly articulated because of the limited space. ${ }^{16}$

\section{Even if only implicitly and often in mysterious ways.}

16.Cf. Urbaniak, J. Attuned to God's reign in the face of Death and Empire [work in progress; to be submitted to the Journal of Theology for Southern Africa in mid-2016].

\section{Acknowledgements}

I am indebted to Prof. Niels Gregersen for his insightful presentation given at the conference held by the South African Science and Religion Forum at UNISA in September 2015 ('Creation, Consciousness and Christology: Evolutionary Perspectives'). It was his remarks that drew my attention in the first place to the organic link between deep incarnation and God's eschatological reign. I am also deeply grateful to Prof. Cornel du Toit who invited me to attend that event. Our stimulating discussions at this and other occasions have fuelled my growing passion for serious theological engagement with sciences. (Jakub Urbaniak)

\section{Competing interests}

The authors declare that they have no financial or personal relationships which may have inappropriately influenced them in writing this article.

\section{Authors' contributions}

Both J.U. and E.O. contributed to the conceptualisation the article. E.O.'s contribution is most evident in the section 'From Jesus' to the ecclesial body: Church vis-à-vis God's reign', which is partly based on his Master's thesis written under the supervision of J.U. at St Augustine College of South Africa in 2015. J.U. was responsible for the writing of the entire article and all revisions; he also prepared the text for submission.

\section{References}

Ambrose of Milan, St, 1880, Sancti Ambrosii Mediolanensis Episcopi Opera Omnia, Patrologia Latina, vol. 16, ed. J.P. Migne, Parisiis Garnier et Migne, Paris.

Cartwright, J., 2013, 'Cosmologist claims universe may not be expanding', Nature, 16 July 2013', viewed 12 February 2016, from http://www.nature.com/news/ cosmologist-claims-universe-may-not-be-expanding-1.13379

Cottrell, S., Croft, S.J.L., Gooder, P. \& Atwell R. (eds.), 2015, Pilgrim. Grow Stage. Book 8: Church \& Kingdom, Church House Publishing, London.

Crawford, N., 2010, 'Theology as improvisation: Seeking the unstructured form of theology with David Tracy', Irish Theological Quarterly 75(3), 300-312. http:// dx.doi.org/10.1177/0021140010368514

Crawford, N., 2013, Theology as improvisation: A study in the musical nature of theological thinking, Brill, Boston, MA.

Cullmann, O., 1950, Christ and time: The primitive Christian concept and history, transl. F.V. Wilson, Westminster Press, Philadelphia, PA.

Daley, B.E., 1991, The hope of the early Church: A handbook of Patristic eschatology, Hendrickson Publishers, Inc., New York.

De Chardin, T., 1964, The future of man, transl. N. Denny, Harper \& Row, New York.

DeCosse, D.E., 2015, 'Review of approaching the end: Eschatological reflections on Church, politics, and life by S. Hauerwas', Theological Studies 76(3), 644. http:// dx.doi.org/10.1177/0040563915593487n

Douglas, M., 1996, Natural symbols: Explorations in cosmology, Routledge, London.

Dulles, A., 1971, 'The Church as eschatological community', in J. Papin (ed.), The Eschaton: A community of love, pp. 69-103, The Villanova University Press, Villanova, PA.

Dulles, A., 1985, Models of the Church, Gill and Macmillan, Dublin.

Fuellenbach, J., 2006, The Kingdom of God: The message of Jesus today, Wipf \& Stock, Eugene, OR.

Gregersen, N.H., 2012, 'The extended body: The social body of Jesus according to Luke', Dialog: A Journal of Theology 51(3), 234-244. http://dx.doi. org/10.1111/j.1540-6385.2012.00689.x

Gregersen, N.H., 2013, 'Deep incarnation and kenosis: In, with, under, and as: A response to Ted Peters', Dialog: A Journal of Theology 52(3), 251-262. http://dx. doi.org/10.1111/dial.12050

Gregersen, N.H., 2014, 'God, matter, and information: Towards a Stoicizing Logos Christology', in P. Davies \& N.H. Gregersen (eds.), Information and the nature of reality: From physics to metaphysics, pp. 319-348, Cambridge University Press, Cambridge. 
Gregersen, N.H., 2015, 'The extended body of Christ: Three dimensions of deep incarnation', in N.H. Gregersen (ed.), Incarnation: On the scope and depth of Christology, pp. 225-251, Fortress Press, Minneapolis, MN.

Gregersen, N.H. \& Görman, U. (eds.), 2007, Design and disorder: Perspectives from science and theology, International Society for Science and Religion, Cambridge.

Hauerwas, S., 2013, Approaching the end: Eschatological reflections on Church, politics, and life, William B. Eerdmans Publishing Company, Grand Rapids, MI.

Hermas, 1997, Revelations to the Shepherd of Hermas: A book of Spiritual Visions, ed. R. Van de Weyer, Triumph Books, Liguori, MO.

James, W., 1956, The will to believe and other essays in popular philosophy, and human immortality, Dover Publications, New York.

Johnson, E.A., 2014, Ask the beasts: Darwin and the god of love. Bloomsbury, London

Johnson, E.A., 2015, 'Jesus and the Cosmos: Soundings in deep Christology', in N.H. Gregersen (ed.), Incarnation: On the scope and depth of Christology, pp. 133-156, Fortress Press, Minneapolis, MN.

Keener, C.S., 2009, The Historical Jesus of the Gospels, William B. Eerdmans Publishing Company, Grand Rapids, MI.

Küng, H., 1968, The Church, Sheed and Ward, New York.

Lampe, P., 2002, 'Paul's concept of a spiritual body', in T. Peters, R. Russell \& M. Welke (eds.), Resurrection: Theological and scientific assessments, pp. 103-114, Eerdmans, Grand Rapids, MI.

Lohfink, G., 2014, No Irrelevant Jesus: On Jesus and the Church Today, transl. L.M. Maloney, Liturgical Press, Collegeville, MN.

Lösel, S., 2001, 'Unapocalyptic theology: History and eschatology in Balthasar's TheoDrama', Modern Theology 17(2), 201-225. http://dx.doi.org/10.1111/1468 0025.00157

Luther, M., 1883-2009, Luthers Werke: Kritische Gesammtausgabe, H. Böhlau, Weimar.

Luther, M., 1963, Luther' Works: Lectures on Galatians 1535 Chapters 1-4, vol. 26, J. Pelikan \& W.A. Hansen (eds.), Concordia, St. Louis.

McBrien, R.P., 1966, The Church in the Thought of Bishop John Robinson, Westminste Press, Philadelphia, PA.

McFague, S., 1993, The body of God: An ecological theology, Fortress Press, Minneapolis, MN.

Moltmann, J., 1967, Theology of hope: On the ground and the implications of a Christian eschatology, transl. J.W. Leitch, Harper \& Row, New York.

Moltmann, J., 1992, The spirit of life: A universal affirmation, transl. M. Kohl, Fortress Press, Minneapolis, MN.

Moltmann, J., 1996, The Coming of God: Christian eschatology, Fortress Press, Minneapolis, MN.

Moltmann, J., 2015, 'Is God incarnate in all that is?' in N.H. Gregersen (ed.) Incarnation: On the scope and depth of Christology, pp. 119-131, Fortress Press, Minneapolis, MN

Moskowitz, C., 2012, 'Speed of universe's expansion measured better than ever', 3 October 2012, viewed 12 February 2016, from http://www.space.com/17884 universe-expansion-speed-hubble-constant.html\#sthash.DNAtZdZx.dpuf

Müller-Fahrenholz, G., 2001, The Kingdom and the power: The theology of Jürgen Moltmann, Fortress Press, Minneapolis, MN.
Musser, D.W. \& Price, J.L., 1996, A new handbook of Christian theologians, Abingdon Press, Nashville, TN.

Pannenberg, W., 1969, Theology and the Kingdom of God, Westminster Press, Philadelphia, PA.

Rahner, K., 1966, Theological investigations, vol. 4: 'More Recent Writings', transl. K. Smyth, Helicon Press, Baltimore, MD.

Rahner, K., 1969, Theological Investigations, vol. 6: 'Concerning Vatican Council II', transl. K.-H. Kruger \& B. Kruger, Helicon Press, Baltimore, MD.

Rahner, K., 1974, 'Dogmatic questions on Easter', Theological Investigations, vol. 4 transl. K. Smyth, Seabury, New York.

Rahner, K., 1975, 'Christology within an evolutionary view of the world', in Theological investigations, vol. 5, transl. K.-H. Kruger, pp. 157-192, Seabury, New York.

Rahner, K., 1982, 'The unity of spirit and matter in the Christian understanding of faith', in Theological investigations, vol. 6, transl. L. Swain, pp. 153-177, Crossroad, New York.

Robinson, J.A.T., 1957, Jesus and his coming, Abingdon Press, New York.

Saul, H., 2013, 'It all started with a bang, but the universe may not be expanding after all Theoretical physicist Christ of Wetterich publishes paper 'a universe without expansion', Independent, 13 August 2013, viewed 12 February 2016, from http:// www.independent.co.uk/news/science/it-all-started-with-a-bang-but-theuniverse-may-not-be-expanding-after-all-8759893.html

Smeulders, P., 2013, 'Why the expansion of the universe appears to accelerate' Journal of Modern Physics 4(6), 780-783, viewed 12 February 2016, from http:// www.scirp.org/journal/PaperInformation.aspx?PaperID $=33000$

Stăniloae, D., 1985, Orthodoxe Dogmatik [Orthodox Dogmatics], vol. 1, Gütersloher Verlagshaus, Gütersloh.

Tracy, D., 1981, The analogical imagination: Christian theology and the culture of pluralism, Peeters Press, Louvain.

University of Arizona, 2015, 'Universe expanding more slowly than previously thought?: Press Release', viewed 12 February 2016, from http://astronomynow. com/2015/04/13/universe-expanding-more-slowly-than-previously-thought/

Urbaniak, J. \& Otu, E., 2016, “'God's Reign as a Hermeneutic Key to Jesus” Eschatological Expectation', HTS Teologiese Studies/Theological Studies 72(1), a3232, xx pages. http://dx.doi.org/10.4102/hts.v72i1.3232

Vatican II, 1963, Sacrosanctum Concilium: Constitution on the sacred liturgy [SC], viewed 12 February 2016, from http://www.vatican.va/archive/hist_councils/ii_vatican_ council/documents/vat-ii_const_19631204_sacrosanctum-concilium_en.html

Vatican II, 1964, Lumen gentium: Dogmatic constitution on the Church [LG], viewed 12 February 2016, from http://www.vatican.va/archive/hist councils/ii vatican council/documents/vat-ii const 19641121 lumen-gentium_en.html

Vatican II, 1965a, Ad Gentes: Decree on the mission activity of the Church [AG], viewed 12 February 2016, from http://www.vatican.va/archive/hist councils/ii vatican council/documents/vat-ii_decree_19651207_ad-gentes_en.h̄tml

Vatican II, 1965b, Gaudium et Spes: Pastoral constitution on the Church in the modern world [GS], viewed 12 February 2016, from http://www.vatican.va/archive/hist councils/ii_vatican_council/documents/vat-ii_const_19651207_gaudium-etspes_en.html

Von Balthasar, H.U., 1964, A theology of history, Sheed and Ward, London.

Welker, M., 2014, 'What is the "Spiritual body"?', in P. Davies \& N.H. Gregersen (eds.), Information and the nature of reality: From physics to metaphysics, pp. 349-364, Cambridge University Press, Cambridge. 